\title{
Blasts 5 Percent or Less of Bone Marrow Nucleated Cells
}

National Cancer Institute

\section{Source}

National Cancer Institute. Blasts 5 Percent or Less of Bone Marrow Nucleated Cells. NCI Thesaurus. Code C137698.

A semi-quantitative microscopic finding indicating that 5 percent or less of the nucleated cells in a bone marrow sample are immature mononuclear cells. 